\title{
Sikap Dan Norma Subyektif Terhadap Niat Konsumen Membeli Motor Yamaha Nmax 155
}

\author{
Roby Irzal Maulana \\ Fakultas Ekonomi Universitas Pamulang, robyirzalmaulana@gmail.com
}

\begin{abstract}
ABSTRAK
Menurut Theory of Reasoned Action dari Fishbein dan Ajzen, menyatakan bahwa tindakan seseorang adalah realisasi dari keinginan atau niat seseorang untuk bertindak. Faktor yang mempengaruhi niat adalah sikap pada tindakan, dan norma subyektif menyangkut persepsi seseorang. Penelitian ini bertujuan untuk mengetahui pengaruh sikap dan norma subyektif terhadap niat konsumen dalam membeli sepeda motor Yamaha Nmax 155 di PT Yamaha Motor Tangerang Selatan. Jumlah sampel penelitian dalam penelitian ini sebanyak 80 orang konsumen. Data dikumpulkan dengan metode observasi, wawancara, studi dokumentasi dan kuesioner. Teknik analisis data menggunakan analisis regresi linier berganda. Berdasarkan hasil analisis menyatakan bahwa sikap dan norma subyektif berpengaruh positif terhadap niat konsumen dalam membeli sepeda motor Yamaha Nmax 155 di PT Yamaha Motor.
\end{abstract}

Kata Kunci : sikap, norma subyektif, niat konsumen membeli produk

\begin{abstract}
According to the Theory of Reasoned Action of Fishbein and Ajzen, states that a person's actions are the realization of a desire or intention of a person to act. Factors affecting the intention is the attitude in action, and subjective norms regarding the perception of a person. This study aims to determine the effect of attitudes and subjective norms on consumer intentions to buy a motorcycle Yamaha Nmax 155 in PT Yamaha Motor South Tangerang. Total sample in this study as many as 80 customers. Data collected by observation, interview, documentation and study questionnaires. Data were analyzed using multiple linear regression analysis. Based on the analysis states that the attitude and subjective norm positive effect on consumer intentions to buy a motorcycle Yamaha Nmax 155.
\end{abstract}

Keywords: attitude, subjective norm, consumer intentions to buy the product

Naskah diterima : 16 Juni 2019, direvisi : 28 Juni 2019, diterbitkan : 16 September 2019

ISSN: 2355-0295, e-ISSN: 2549-8932

http://ejournal.bsi.ac.id/ejurnal/index.php/ecodemica 


\section{PENDAHULUAN}

Dalam era globalisasi persaingan bisnis menjadi sangat tajam pada semua bidang usaha, baik usaha di pasar domestik maupun di pasar internasional. Perkembangan dunia bisnis yang sangat cepat membuat pihak-pihak di dalamnya harus bekerja lebih keras agar keberadaannya tetap diakui oleh pelanggan mereka. Hal ini ditandai dengan semakin banyaknya berdiri perusahaan baru dan semakin berkembangnya perusahaan yang ada. Bervariasinya merek dan jenis produk yang ditawarkan di pasaran menunjukan bahwa perusahaan tidak dapat hanya berdiam diri dalam melakukan bisnisnya. keadaan seperti ini tentu saja menimbulkan banyak persaingan di antara perusahaan yang menghasilkan produk sejenis maupun perusahaan yang menghasilkan produk yang berbeda dalam merebut pasar. Saat ini diyakini bahwa kunci utama untuk memenangkan persaingan adalah dengan memahami serta memuaskan kebutuhan dan keinginan konsumen melalui penyampaian produk atau jasa yang berkualitas serta harga yang bersaing, hal ini bertujuan agar konsumen tidak beralih ke perusahaan lain sehingga akan menciptakan loyalitas konsumen.

Sepeda motor adalah kendaraan roda dua yang sangat dibutuhkan dan digunakan masyarakat Tangerang Selatan, khususnya sebagai sarana transportasi yang praktis. Kendaraan bermotor roda dua sebagai salah satu sarana transportasi darat, dewasa ini semakin meningkat pemakaiannya. Jumlah penduduk Tangerang Selatan sampai tahun 2019 yaitu sebanyak 4.104.900 orang (http://bali.bps.go.id, 2015) menjadi potensi pangsa pasar yang menjanjikan bagi industri sepeda motor, dengan jumlah terbesar ada di Kota Tangerang Selatan yaitu 708.454 orang.
Saat ini para produsen motor masih menganggap Tangerang khususnya Kota Tangerang Selatan sebagai salah satu pasar yang paling prospektif karena permintaan konsumen masih tetap tinggi. Ini artinya peluang mengisi pasar otomotif terutama kendaraan roda dua di Tangerang Selatan masih terbuka lebar. Mewabahnya motor maxi matic di kalangan konsumen Tangerang Selatan juga merupakan fenomena tersendiri yang tidak terjadi di daerah-daerah lain untuk memenuhi kebutuhan.

Menurut Mas'ud (2012) studi tentang sikap merupakan kunci untuk dapat memahami mengapa seseorang berperilaku. Disamping itu, sikap merupakan hasil evaluasi yang mencerminkan rasa suka atau tidak suka terhadap objek, sehingga dengan mengetahui hasil evaluasi tersebut, kita dapat menduga seberapa besar potensi pembelian seseorang. Pernyataan ini dipertegas oleh Fausiah dan Wahyu (2010) yang menyatakan bahwa sikap terhadap perilaku adalah derajat penilaian atau kepercayaan-kepercayaan (beliefs) positif atau negatif seseorang terhadap suatu perilaku. Sikap ini ditentukan oleh beliefs seseorang mengenai konsekuensi positif atau negatif dari melakukan suatu perilaku (behavioral beliefs), ditimbang berdasarkan hasil evaluasi dari konsekuensi berperilaku tersebut (outcome evaluation).

\section{KAJIAN LITERATUR}

PT Yamaha Motor adalah salah satu main dealer resmi sepeda motor merek Yamaha yang bergerak dalam bidang penjualan dan perawatan kendaraan. Dengan menjual berbagai macam produk sepeda motor yang menarik, fitur yang beragam dan berkualitas maka akan dengan mudah menarik minat konsumen untuk membeli produk yang ditawarkan. Adapun jumlah konsumen untuk masing-masing jenis 
sepeda motor Yamaha di PT Yamaha Motor Tangerang Selatan tahun 2019 dapat dilihat pada Tabel 1. Berdasarkan Tabel 1 dapat dilihat bahwa PT Yamaha Motor Tangerang Selatan menjual berbagai jenis sepeda motor merek Yamaha untuk memenuhi kebutuhan konsumen. Data ini menunjukkan bahwa Yamaha Nmax 155 mempunyai jumlah penjualan tertinggi dari berbagai jenis varian Yamaha yang ditawarkan.

\section{Tabel 1.}

\section{Jumlah Konsumen Masing- masing Jenis Sepeda Motor Yamaha di PT Yamaha Motor Tangerang Selatan Tahun 2019}

No. Jenis Sepeda Motor Yamaha Jumlah
Konsumen

$\begin{array}{lll}1 & \text { Nmax 155 } & 1.250 \\ 2 & \text { Yamaha Vixion } & 850 \\ 3 & \text { Yamaha R15 } & 524 \\ 4 & \text { Yamaha R25 } & 432 \\ 5 & \text { Yamaha Xmax } & 252 \\ 6 & \text { Yamaha MT 25 } & 223\end{array}$

Sumber: PT Yamaha Motor Tangerang Selatan, tahun 2019.

Sepeda motor Yamaha Nmax 155 memiliki keunggulan dari segi desain eksterior, kenyamanan berkendara, kualitas, dan keamanan serta berbagai macam warna menarik yang di tawarkan, dengan harga jual kembali yang tinggi jika dibandingkan dengan varian lainnya.

H1 : Sikap dan norma subyektif berpengaruh positif dan signifikan terhadap niat konsumen dalam membeli sepeda motor Yamaha Nmax 155 di PT Yamaha Motor Tangerang Selatan.

\section{METODE PENELITIAN}

Penelitian ini menggunakan pendekatan kuantitatif dalam bentuk asositaif yang menunjukkan hubungan antar variabel yang ada dalam penelitian.

Penelitian ini dilakukan dengan tujuan untuk mengetahui hubungan dari sikap dan norma subyektif terhadap niat konsumen membeli sepeda motor Yamaha Nmax 155. Penelitian ini dilakukan di PT Yamaha Motor Tangerang Selatan, yang beralamat di Jalan Raden Saleh Karang Tengah, Kota Tangerang Selatan Banten. Alasan dalam memilih lokasi penelitian di PT Yamaha Motor Tangerang Selatan karena terletak pada lokasi yang sangat strategis di pusat kota dan pada wilayah perumahan, perkantoran, dan perdagangan sehingga strategis dalam menjalankan usaha. Adapun yang menjadi objek penelitian dalam penelitian ini adalah bidang manajemen pemasaran, yaitu sikap, norma subyektif, dan niat konsumen dalam membeli sepeda motor Yamaha Nmax 155. Variabel terikat dalam penelitian ini adalah niat konsumen dalam membeli sepeda motor Yamaha Nmax 155 (Y).

Variabel bebas (independent variable) merupakan variabel yang dapat mempengaruhi variabel lain (Sugiyono, 2012). Variabel bebas dalam penelitian ini adalah sikap (X1) dan norma subyektif 
(X2). Definisi variabel penelitian secara operasional berkaitan dengan obyek penelitian, dibatasi oleh tempat dan faktorfaktor penentu (indikator) variabel, yaitu sikap (X1), norma subyektif (X2), dan niat konsumen dalam membeli sepeda motor Yamaha Nmax 155 (Y).

Definisi variabel penelitian dapat dilihat pada Tabel 2 .

Tabel 2.

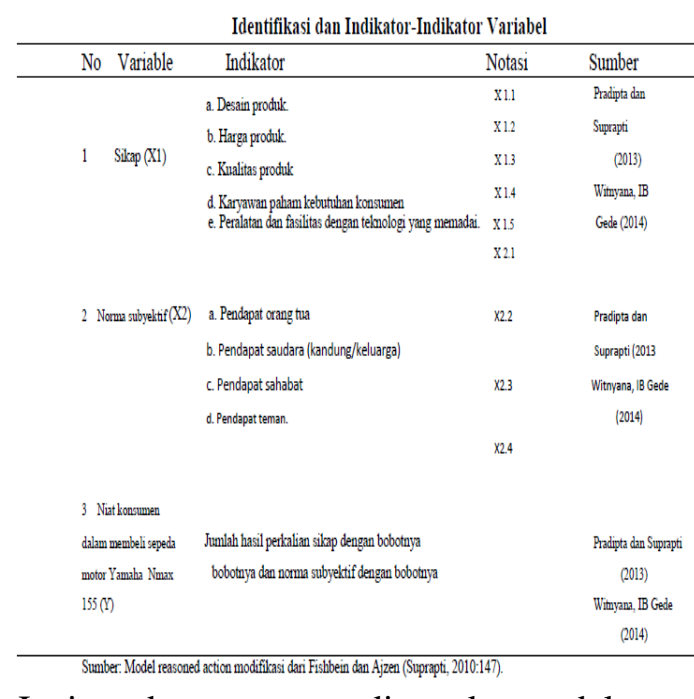

Jenis data yang digunakan dalam penelitian ini terdiri dari data kuantitatif yang berupa angka-angka dan dapat dihitung, seperti jumlah konsumen dan skor jawaban kuesioner sikap, norma subyektif, dan skor niat konsumen dalam membeli sepeda motor Yamaha Nmax 155 , serta data kualitatif yang tidak berupa angka-angka dan tidak dapat dihitung, seperti sejarah perusahaan, struktur organisasi, dan aktivitas pemasaran PT Yamaha Motor Tangerang Selatan.

Populasi dalam penelitian ini adalah jumlah konsumen yang mengunakan sepeda motor Yamaha Nmax 155 di PT Yamaha Motor Tangerang Selatan tahun 2019, sebanyak 1.200 orang konsumen. Sebagai bagian dari populasi, sampel memberikan gambaran yang benar tentang populasi (Mulyono, 2010:173). Sampel dalam penelitian ini ditentukan dengan rumus Slovin (Umar, 2011:108), yaitu:

$\mathrm{n}=\frac{\mathrm{N}}{1+\mathrm{Ne}}$

Keterangan:

$\mathrm{n}=$ Ukuran sampel

$\mathrm{N}=$ Populasi

$\mathrm{e}=$ Persentase kelongaran ketidaktelitian karena kesalahan pengambilan sampel yang masih dapat ditolerir atau diinginkan.

Diketahui:

$\mathrm{N}=1.202$ orang konsumen $\mathrm{e}=10$ persen atau 0,1

Perhitungan ukuran sampel: 1.202

$$
\begin{aligned}
& \mathrm{n}=\frac{1.202}{1+1.202(0,1) 2} \\
& =\frac{1.202}{1+1.202(0,01)} \\
& =\frac{1.202}{13,02} \\
& \mathrm{n}=92,32=92 \text { orang }
\end{aligned}
$$

(dibulatkan)

Hasil perhitungan tersebut diketahui jumlah sampel penelitian sebanyak 80 orang konsumen sepeda motor Yamaha Nmax 155 di PT Yamaha Motor Tangerang Selatan. Metode pengambilan sampel dalam penelitian ini menggunakan metode purposive sampling yaitu metode penentuan sampel non-probabilitas dengan beberapa kriteria pertimbangan tertentu (Sugiyono, 2012:122). Kriteria yang dimaksud adalah: 1) sampel adalah konsumen yang menggunakan sepeda 
motor Yamaha Nmax 155 di PT Yamaha Motor Tangerang Selatan, dan 2) berpendidikan minimal SMA dengan usia minimal 21 tahun. Kriteria yang kedua dengan sengaja ditentukan agar responden memahami dengan baik substansi butirbutir pernyataan dalam kuesioner.

Metode pengumpulan data yang digunakan dalam penelitian ini adalah wawancara dengan pimpinan dan karyawan perusahaan yang berkompeten yang berhubungan dengan penelitian, seperti sejarah singkat berdirinya perusahaan, struktur organisasi, deskripsi jabatan, aktivitas pemasaran di PT Yamaha Motor Tangerang Selatan dan keluhan konsumen berkaitan dengan atribut sepeda motor Yamaha Nmax 155 yang mempengaruhi sikap konsumen. Penelitian ini juga menggunakan kuesioner yang disebarkan kepada responden (konsumen) berkaitan dengan niat konsumen dalam membeli sepeda motor Yamaha Nmax 155 di PT Yamaha Motor Tangerang Selatan, sikap, dan norma subyektif. Kuisioner dalam penelitian ini menggunakan skala Likert. Menurut Riduwan dan Sunarto (2012:29) skala Likert yaitu skala yang digunakan untuk mengukur sikap, pendapat, dan persepsi seseorang atau sekelompok orang tentang fenomena sosial. Setiap jawaban kuesioner mempunyai bobot atau skor nilai dengan skala Likert sebagai berikut :

1) Sangat Tidak Setuju (STS), diberi skor 1; 2) Tidak Setuju (TS), diberi skor 2;3) Cukup Setuju (CS), diberi skor 3;4) Setuju (S), diberi skor 4; dan 5) Sangat Setuju (SS), diberi skor 5.

Uji validitas dan reliabilitas instrumen penelitian penting dilakukan didalam suatu penelitian. Instrumen yang valid berarti alat ukur yang digunakan untuk mendapatkan data dapat digunakan untuk mengukur apa yang seharusnya diukur, sehingga diharapkan nanti hasil penelitian akan menjadi valid. Menurut Sugiyono (2012:172), ketentuan suatu instrumen dikatakan valid atau sahih apabila memiliki koefisien korelasi Pearson Product Moment $(r)>0,3$ dengan alpha sebesar 0,05 . Instrumen yang reliable adalah instrumen yang bila digunakan beberapa kali untuk mengukur obyek yang sama, akan menghasilkan data yang sama. Suatu instrumen dikatakan reliable, apabila memiliki koefisien alpha $(\alpha)$ lebih besar dari 0,60. Setelah diketahui validitas dan reliabilitas instrumen penelitian, maka selanjutnya baru dilakukan analisis data. Penelitian ini menggunakan analisis data berupa analisis regresi linier berganda. Analisis regresi berganda ini dipergunakan untuk menjawab Hipotesis 1 dan Hipotesis 2. Model regresi berganda yang dipergunakan dalam penelitian ini adalah:

$$
\hat{\mathrm{Y}}=\alpha+\beta 1 \mathrm{X} 1+\beta 2 \mathrm{X} 2+
$$

ei.

Keterangan:

$\hat{Y}=$ Niat konsumen dalam membeli sepeda motor Honda Vario Techno 125 CBS

$$
\begin{aligned}
& \alpha=\text { Nilai konstanta } \\
& X_{1}=\text { Sikap } \\
& X_{2}=\text { Norma subyektif } \\
& \beta_{1}=\text { Koefisien regresi dari }
\end{aligned}
$$

sikap (X1)

$\beta_{2}=$ Koefisien regresi dari norma subyektif (X2)

$$
\text { ei }=\text { Faktor residual }
$$




\section{PEMBAHASAN}

Karakteristik responden pada penelitian ini dilihat dari beberapa kriteria, yaitu: umur, jenis kelamin, pendidikan terakhir, pekerjaan dan pendapatan per bulan. Karakteristik tersebut disajikan dalam Tabel 3.

Tabel 3 menjelaskan karakteristik responden penelitian di PT Yamaha Motor Tangerang Selatan. Dilihat dari umur, dapat diketahui bahwa jumlah konsumen yang berumur antara 31-40 tahun lebih banyak dalam membeli sepeda motor Yamaha Nmax 155 di PT Yamaha Motor Tangerang Selatan, yakni 44 orang, dengan persentase terbesar yaitu 47,83 persen. Hal ini disebabkan karena usia 31 sampai dengan 40 tahun adalah usia yang paling produktif dalam melakukan aktivitas, termasuk dalam pembelian produk.

Dilihat dari persentase jenis kelamin, konsumen laki-laki mempunyai persentase yang lebih besar dalam membeli sepeda motor Yamaha Nmax 155 di PT Yamaha Motor Tangerang Selatan yaitu sebanyak 62 orang atau sebesar 67,39 persen dibandingkan dengan konsumen perempuan yaitu sebanyak 30 orang atau sebesar 32,61 persen.

\section{Tabel 3}

Karakteristik Responden di PT

Yamaha Nmax 155 di PT Yamaha Motor Tangerang Selatan

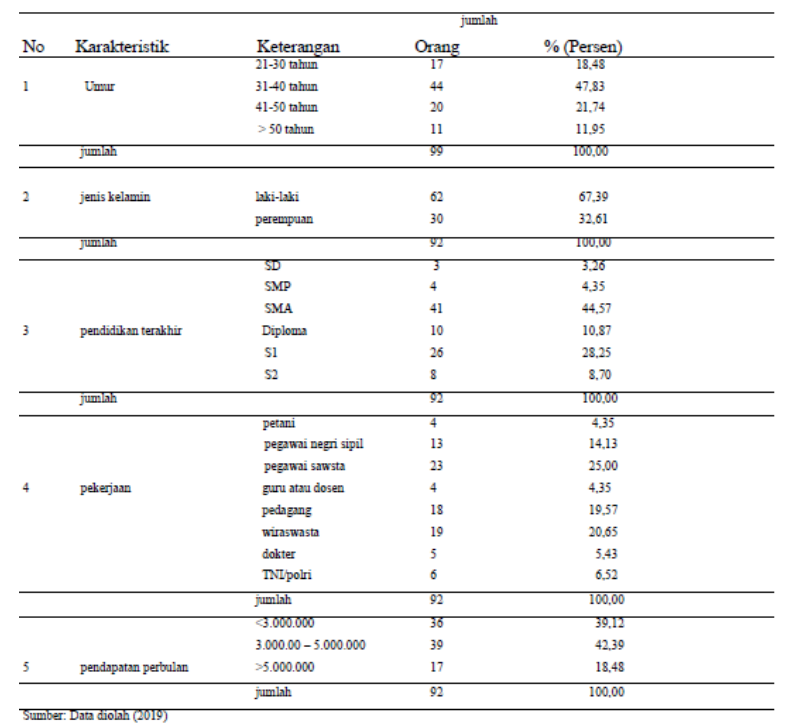

Dilihat dari persentase jenis kelamin, konsumen laki-laki mempunyai persentase yang lebih besar dalam membeli sepeda motor Yamaha Nmax 155 di PT Yamaha Motor Tangerang Selatan yaitu sebanyak 62 orang atau sebesar 67,39 persen dibandingkan dengan konsumen perempuan yaitu sebanyak 30 orang atau sebesar 32,61 persen.

Tingkat pendidikan terakhir konsumen yang mendominasi dalam membeli sepeda motor Yamaha Nmax 155 di PT Yamaha Motor Tangerang Selatan adalah SMA yaitu sebanyak 41 orang atau sebesar 44,57 persen, selanjutnya adalah S1 sebanyak 26 orang atau sebesar 28,25 persen, Diploma sebanyak 10 orang atau sebesar 10,87 persen, S2 sebanyak 8 orang atau sebesar 8,70 persen, SMP sebanyak 4 orang atau sebesar 4,35 persen dan terakhir adalah SD sebanyak 3 orang atau sebesar 3,26 persen.

Dilihat dari jenis pekerjaan konsumen yang membeli sepeda motor Yamaha Nmax 155 di PT Yamaha Motor Tangerang Selatan, pembelian didominasi 
oleh pegawai swasta yakni sebanyak 23 orang atau sebesar 25 persen.

Ditinjau dari pendapatan diketahui responden dengan pendapatan Rp.3.000.000,- sampai Rp.5.000.000,- per bulan adalah yang terbanyak membeli sepeda motor Yamaha Nmax 155 di PT Yamaha Motor Tangerang Selatan yaitu 39 orang atau sebesar 42,39 persen. selanjutnya pendapatan kurang dari Rp.3.000.000,- per bulan adalah 36 orang atau sebesar 39,13 persen dan pendapatan lebih dari Rp.5.000.000,- per bulan sebanyak 17 orang atau sebesar 18,48 persen

Pengujian validitas dan reliabilitas masing-masing instrumen penelitian yang diperoleh dari jawaban kuesioner sangat penting dilakukan untuk memperoleh hasil penelitian yang valid dan reliable. Valid berarti instrumen tersebut dapat digunakan untuk mengukur apa yang seharusnya diukur. Reliable berarti instrumen penelitian tersebut bila digunakan beberapa kali untuk mengukur obyek yang sama, akan menghasilkan data yang sama. Hasil uji validitas dan reliabilitas instrumen penelitian di PT Yamaha Motor Tangerang Selatan, dapat dilihat pada Tabel 4.
Tabel 4.

Rekapitulasi Hasil Uji Validitas dan Reliabilitas Instrumen Penelitian

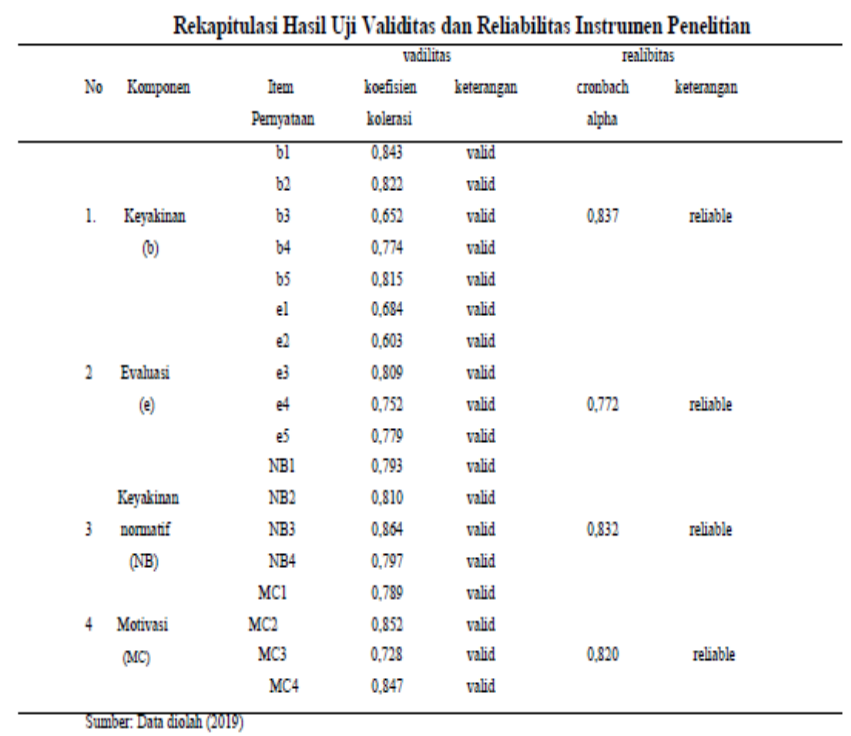

Berdasarkan Tabel 4 maka dapat ditunjukkan bahwa instrumen penelitian variabel sikap (keyakinan dan evaluasi) dan variabel norma subyektif (keyakinan normatif dan motivasi) seluruhnya adalah valid dan reliable. Dikatakan valid karena memiliki koefisien korelasi > 0,30 dan reliable karena koefisien Cronbach alpha $>0,60$. Hal ini berarti instrumen penelitian adalah sah yaitu pernyataan-pernyataan pada kuesioner mampu mengungkapkan apa yang diukur oleh kuesioner tersebut dan handal karena jawaban tiap responden dianggap konsisten atau stabil dari waktu ke waktu.

Untuk mengetahui pengaruh sikap dan norma subyektif terhadap niat konsumen dalam membeli sepeda motor Yamaha Nmax 155 di PT Yamaha Motor Tangerang Selatan, maka digunakan analisis regresi linear berganda. Analisis tersebut diolah dengan paket program komputer, yaitu Statistical Package for Social Science (SPSS). Uji normalitas adalah pengujian tentang kenormalan 
distribusi data artinya data memusat pada nilai rata-rata (mean) dan median (Ghozali, 2012). Keputusan untuk menentukan normal atau tidaknya distribusi data, dilakukan dengan analisis statistik menggunakan uji KolmogorovSmirnov, seperti pada Tabel 5.

Tabel 5

Hasil Uji Kolmogorov-Smirnov

\begin{tabular}{|c|c|}
\hline & Unstadardizat Residual \\
\hline II & 9 \\
\hline Bolmogoror-Smimoofz & 1,131 \\
\hline 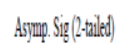 & 0,155 \\
\hline
\end{tabular}

Berdasarkan Tabel 5 dapat diketahui bahwa nilai Asymp. Sig (2-tailed) sebesar 0,155 lebih besar dari 0,05 . Hal ini menjelaskan bahwa model regresi sudah memenuhi asumsi normalitas atau data berdistribusi normal, sehingga dapat dilanjutkan untuk analisis selanjutnya.

Uji heteroskedastisitas artinya uji yang dimana variance dari residual tidak sama untuk satu pengamatan ke pengamatan yang lain. Jika variance dari residual satu pengamatan ke pengamatan yang lain tetap, maka disebut homoskedastisitas dan jika berbeda disebut heteroskeastisitas. Model regresi yang baik adalah yang homoskedastisitas atau tidak terjadi heteroskedastisitas. Mendeteksi ada tidaknya heteroskedastisitas dapat dilihat dari Grafik Plot antara nilai-nilai prediksi variabel terikat yang terstandarisasi atau ZPRED (standardized predicted values) dengan nilai residualnya yang terstandarisasi atau SRESID (standardized residual). Gambar Scatterplot Output regression dapat dilihat pada Gambar 1.
Regression Standardized Predicted Value

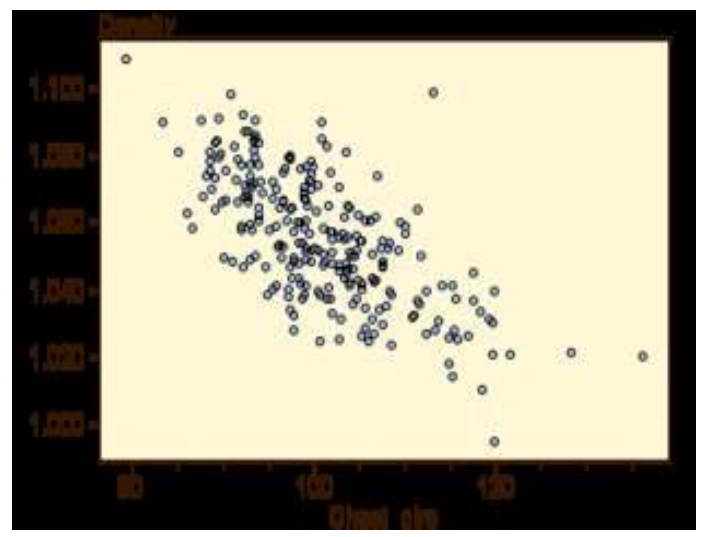

Gambar 1.

Hasil Uji Heteroskedastisitas Sumber: Data diolah (2016)

Gambar scatterplot output regression menjelaskan bahwa penyebaran residual menunjukkan tidak ada pola yang jelas, serta titik-titik menyebar di atas dan di bawah angka 0 pada sumbu $Y$ tidak teratur. Hasil yang demikian menunjukkan bahwa tidak terjadi heteroskedastisitas (plotnya tidak terpencar dan membentuk pola tertentu). Uji multikolinearitas menyatakan bahwa dalam regresi berganda gejala korelasi antar variabel bebas seharusnya tidak ada. Multikolinearitas dapat dilihat dari nilai tolerance dan lawannya yaitu variance inflation factor (VIF). Nilai Tolerance dan VIF dapat dilihat pada Tabel 6. 
Tabel 6

\begin{tabular}{|c|c|c|c|}
\hline 10 & radule totos & tolexce & 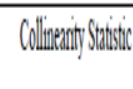 \\
\hline 1 & Sitax $(\mathrm{XI})$ & 0,956 & 1,46 \\
\hline$l$ & Som Stowedif(X) & 0,956 & 1,06 \\
\hline
\end{tabular}

Berdasarkan Tabel 6 dapat dilihat bahwa nilai VIF dibawah 10 dan nilai Tolerance dibawah 1 menjelaskan tidak terjadi multikolinearitas atau tidak terjadi korelasi diantara variabel sikap dan norma subyektif.

Penelitian ini menggunakan model persamaan regresi linier berganda untuk mengetahui pengaruh sikap dan norma subyektif terhadap niat konsumen dalam membeli sepeda motor Yamaha Nmax 155. Hasil pengujian disajikan pada Tabel 7.

Berdasarkan hasil yang diperoleh dari rekapitulasi hasil analisis regresi linier berganda berdasarkan pada hasil koefisien regresi pada Tabel 7 adalah sebagai berikut:

$\hat{\mathrm{Y}}=4,535+0,491 \mathrm{X} 1+0,426 \mathrm{X} 2+\mathrm{e}$
Tabel 7

\begin{tabular}{|c|c|c|c|c|}
\hline \multirow{2}{*}{\multicolumn{2}{|c|}{$\begin{array}{l}\text { Unstandardized } \\
\text { Coefficients }\end{array}$}} & \multirow{3}{*}{$\begin{array}{l}\text { Standardized } \\
\text { Coefficients } \\
\text { beta }\end{array}$} & \multirow[t]{3}{*}{$t$} & \multirow[t]{3}{*}{$\mathrm{sg}$} \\
\hline & & & & \\
\hline B & std.eror & & & \\
\hline 4,535 & 2,842 & & 1,595 & 0,114 \\
\hline 0,491 & 0,037 & 0,673 & 13,404 & 0,000 \\
\hline \multirow[t]{3}{*}{0,426} & 0,047 & 0,453 & 9,015 & 0,000 \\
\hline & & $\begin{array}{r}0,786 \\
163,088\end{array}$ & & \\
\hline & & 0,000 & & \\
\hline
\end{tabular}

Uji Simultan (Uji F), berdasarkan hasil perhitungan uji $\mathrm{F}$ menunjukkan nilai dari uji $\mathrm{F}$ dalam penelitian sebesar 163,088 dengan signifikansi uji $F$ sebesar $0,0000,000<0,05$ yang artinya model regresi ini layak untuk digunakan.

Koefisien determinasi (R2) menunjukkan seberapa jauh kemampuan variable bebas (independen) menerangkan variabel terikatnya (dependen). Berdasarkan Tabel 6 nilai R 2 sebesar 0,786, ini berarti kontribusi secara simultan antara perubahan sikap dan norma subyektif terhadap perubahan niat konsumen dalam membeli sepeda motor Yamaha Nmax 155 adalah sebesar 78,60 persen, sedangkan sisanya 21,40 persen dijelaskan oleh variabel lain di luar perubahan sikap dan norma subyektif yang tidak dibahas dalam penelitian ini.

Pengujian Hipotesis 1, dari hasil perhitungan Tabel 7 diperoleh nilai $\mathrm{t}$ hitung sebesar 1,595, nilai koefisien regresi variabel sebesar 4,535 dengan tingkat signifikansi uji F $0,000<0,05$. Hasil ini menunjukkan signifikansi yang lebih kecil dari 0,05. Ini berarti bahwa seluruh variabel bebas secara simultan berpengaruh signifikan terhadap niat 
konsumen dalam membeli sepeda motor $\mathrm{H}$ Yamaha Nmax 155 di PT Yamaha Motor Tangerang Selatan, sehingga hipotesis pertama dalam penelitian ini diterima. Nilai positif menjelaskan adanya pengaruh yang searah, yaitu apabila sikap dan norma subyektif meningkat maka akan diikuti oleh meningkatnya niat konsumen dalam membeli sepeda motor Yamaha Nmax 155 di PT Yamaha Motor Tangerang Selatan. Hasil penelitian sekarang sejalan dengan penelitian Cheng, dkk (2011) menemukan bahwa secara simultan sikap dan norma subyektif mengarahkan dampak positif terbesar pada niat pelanggan untuk membeli produk.

Pengujian Hipotesis 2, dari hasil perhitungan Tabel 7 diperoleh nilai $\mathrm{t}$ hitung sebesar 13,404, nilai koefisien regresi variabel sikap sebesar 0,491 dengan tingkat signifikansi uji $\mathrm{t}$ $0,000<0,05$. Hasil ini menunjukkan signifikansi yang lebih kecil dari 0,05. Ini berarti bahwa sikap secara parsial berpengaruh positif dan signifikan terhadap niat konsumen dalam membeli sepeda motor Yamaha Nmax 155 di PT Yamaha Motor Tangerang Selatan, sehingga hipotesis kedua dalam penelitian ini diterima. Nilai positif menjelaskan adanya pengaruh yang searah, yaitu apabila sikap meningkat maka akan diikuti oleh meningkatnya niat konsumen dalam membeli sepeda motor Yamaha Nmax 155 di PT Yamaha Motor Tangerang Selatan. Hasil penelitian ini sesuai dengan penelitian sebelumnya oleh Raj (2012) diperoleh bahwa sikap konsumen berpengaruh positif terhadap niat berperilaku konsumen secara terencana.

Pengujian Hipotesis 3, dari hasil perhitungan Tabel 7 diperoleh nilai $\mathrm{t}$ hitung sebesar 9,015, nilai koefisien regresi variabel norma subyektif sebesar 0,426 dengan tingkat signifikansi uji $\mathrm{t}$ $0,000<0,05$. Hasil ini menunjukkan signifikansi yang lebih kecil dari 0,05. Ini berarti bahwa norma subyektif secara parsial berpengaruh positif dan signifikan terhadap niat konsumen dalam membeli sepeda motor Yamaha Nmax 155 di PT Yamaha Motor Tangerang Selatan, sehingga hipotesis kedua dalam penelitian ini diterima. Nilai positif menjelaskan adanya pengaruh yang searah, yaitu apabila norma subyektif meningkat maka akan diikuti oleh meningkatnya niat konsumen dalam membeli sepeda motor Yamaha Nmax 155 di PT Yamaha Motor Tangerang Selatan. Hasil penelitian sekarang sejalan dengan temuan penelitian Titah dan Barki (2009) dalam penelitiannya menemukan bahwa norma subyektif adalah sebagai penentu untuk memprediksi niat untuk menggunakan produk.

\section{PENUTUP}

Berdasarkan hasil analisis data dan pembahasan yang telah diuraikan pada bab sebelumnya, dapat disimpulkan bahwa variabel sikap konsumen dan variabel norma subyektif, baik secara simultan maupun parsial berpengaruh positif dan signifikan terhadap niat konsumen dalam membeli sepeda motor Yamaha Nmax 155 di PT Yamaha Motor Tangerang Selatan. Berdasarkan kesimpulan yang telah disampaikan sebelumnya, maka saran yang dapat diberikan bagi manajemen perusahaan adalah dengan meningkatkan komunikasi pemasaran untuk mempengaruhi sikap konsumen terhadap niat konsumen dalam membeli sepeda motor Yamaha Nmax 155 di PT Yamaha Motor Tangerang Selatan terutama berkaitan dengan kualitas produk. Dari segi norma subjektif, pihak manajemen perusahaan perlu lebih menguatkan niat konsumen, misalnya dengan cara mengundang konsumen beserta keluarga atau koleganya dalam berbagai kegiatan 
kelompok sosial ataupun mengadakan acara di berbagai tempat dan event sebagai media mempromosikan sepeda motor Yamaha Nmax 155 di PT Yamaha Motor Tangerang Selatan. Selain itu bagi penelitian selanjutnya dapat menjadikan penelitian ini sebagai referensi dengan menggunakan atau menambah variabel lain yang berpengaruh terhadap keputusan konsumen dalam membeli produk, seperti bauran pemasaran, kualitas pelayanan dan brand equity (kualitas merek).

\section{REFERENSI}

Andika, Manda dan Iskandarsyah Madjid. 2012. Analisis Pengaruh Sikap, Norma Subyektif dan Efikasi Diri Terhadap Intensi Berwirausaha Pada Mahasiswa Fakultas Ekonomi Universitas Syiah Kuala (Studi Pada Mahasiswa Fakutas Ekonomi Universitas Syiah Kuala). Eco-Entrepreneurship Seminar and Call for Paper "Improving Performance by Improving Environment, Hal. 190-197.

Fausiah, Masyitha Muis dan Atjo Wahyu. 2010. Pengaruh Sikap, Norma Subyektif, dan Persepsi Kontrol Perilaku Terhadap Intensi Karyawan Untuk Berperilaku K3 di Unit PLTD PT PLN (Persero) Sektor Tello Wilayah Sulselbar (Aplikasi TPB). Jurnal Bagian Kesehatan dan Keselamatan Kerja FKM Unhas, Makassar, Hal. 1-12 Vol 2, No. 5 Juli.

Fredereca, Bunga Geofanny dan Chairy. 2010. Pengaruh Psikologi Konsumen Terhadap Keputusan Pembelian Kembali Smartphone Blackberry. Jurnal Manajemen
Teori dan Terapan Tahun 3, No. 2, Hal. 128-143.

Ghozali, Imam. 2012. Aplikasi Analisis Multivariat dengan Program IBM SPSS 20 Upadate PLS Regresi. Semarang: Badan Penerbit Universitas Diponegoro.

Istiana, Laili. 2010. Pengaruh Sikap, Norma Subyektif dan Kontrol Keperilakuan Terhadap Niat dan Perilaku Beli Produk Susu Ultra High Temperature. Jurnal Fakultas Peternakan Universitas Gajahmada, Yogyakarta, Hal.507512. Kotler, Philip. 2008. Manajemen Pemasaran Jilid 1. Jakarta: PT Indeks Kelompok Gramedia.

Lamb Jr., Charles W. 2008. Pemasaran, Buku 1. Jakarta: Salemba Empat.

Nurtantiono, Andri. 2011. Analisis Sikap

Pelaku Bisnis Terhadap

Perbankan Syariah di Kota Surakarta. Jurnal Graduasi Vol. 26, Hal. 61-74.

Raj, Maria Antony. 2012. Consumer Attitude and Purchase Decision Towards Household Computers (With Reference to Vellore District of Tamilnadu). Asian Journal of Research in Social Science and Humanities Vol. 2 Issue 4, pp. 49-60.

Riduwan dan Sunarto. 2012. Pengantar

Statistika Untuk Penelitian Pendidikan, Sosial, Ekonomi, dan Bisnis. Bandung: Alfabeta.

Rivai, Ahmad. 2010. Perilaku Konsumen Sayuran Organik di Kota Pekanbaru. Jurnal Industri dan Perkotaan Volume XII Nomor 22, Hal.1786-1792. 
Roring, Ferdy. 2011. Pengaruh Sikap, Norma Subyektif dan Kontrol Perilaku Terhadap Minat Menggunakan Internet Banking pada Bank Rakyat Indonesia Cabang Kotamobagu. Jurnal Fakultas Ekonomi Universitas Gajahmada, Yogyakarta, Volume 5 Hal.1-14.

Sigit, Murwanto. 2011. Pengaruh Sikap dan Norma Subyektif Terhadap Niat Beli Mahasiswa Sebagai Konsumen Potensial Produk Pasta Gigi Close Up. Jurnal Siasat Bisnis Vol. 11 No. 1, Hal. 81-91.

Sugiyono. 2012. Metode Penelitian Bisnis. Bandung: Alfabeta.

Sumarwan, Ujang. 2011. Perilaku Konsumen, Teori dan Penerapannya Dalam Pemasaran. Jakarta: Ghalia Indonesia.

Suprapti, Ni Wayan Sri. 2010. Perilaku Konsumen Pemahaman Dasar dan Aplikasinya Dalam Strategi Pemasaran. Denpasar: Udayana University Press.

Umar, Husein. 2011. Riset Sumber Daya Manusia Dalam Organisasi. Jakarta: PT Gramedia Pustaka Utama.

Witnyana, IB Gede. 2014. Pengaruh Sikap dan Norma Subyektif Terhadap Niat Nasabah Dalam Memilih Kredit Tanpa Agunan pada Bank Permata Cabang Denpasar. Skripsi Fakultas Ekonomi dan Bisnis Universitas Udayana.

\section{BIODATA PENULIS}

Roby Irzal Maulana seorang dosen dari Universitas Pamulang Program Studi Manajemen dengan jabatan fungsional Asisten Ahli, beliau menempuh pendidikan formal S1 di Universitas Jenderal Soedirman dan S2 Magister Manajemen Di Universitas Muhammadiyah Jakarta 